\section{EXAMINATION OF SCIENCE SELF- REGULATION SKILLS OF GIFTED AND NON-GIFTED STUDENTS}

\begin{abstract}
The study aimed to examine and compare the science self-regulation skills of gifted and non-gifted students in this study. Survey design, one of the quantitative methods, was utilized in the research. The sample of the study consisted of 263 gifted students enrolled in science and art center and 482 non-gifted students located in the Eastern Anatolia Region of Turkey. Science Self-regulation Scale was used as a data collection tool in the research. Independent samples t-test and one-way analysis of variance were used in the analysis of the data. The findings showed that gifted and non-gifted students had high self-regulation skills towards science. In addition, it was found that although there was no statistically significant difference between the average scores of gifted female and male students on the overall scale, there was a significant difference in the other group. Moreover, while the difference between the mean scores obtained in the dimensions of Refinement, Time Organizing, Organizing, Help Seeking, Metacognitive Self-regulation, and Repetition was in favor of gifted students, it was in favor of non-gifted students regarding the mean scores of critical thinking and effort regulation dimensions. The conclusion and implication were discussed in line with these findings.
\end{abstract}

\section{KEYWORDS}

Science, self-regulation, gifted students, non-gifted students, survey

\section{HOW TO CITE}

Nacaroğlu O., Bektaş O., Tüysüz M. (2021) 'Examination of Science Self-Regulation Skills of Gifted and Non-Gifted Students', Journal on Efficiency and Responsibility in Education and Science, vol. 14, no. 4, pp. 230-246. http://dx.doi.org/10.7160/eriesj.2021.140403

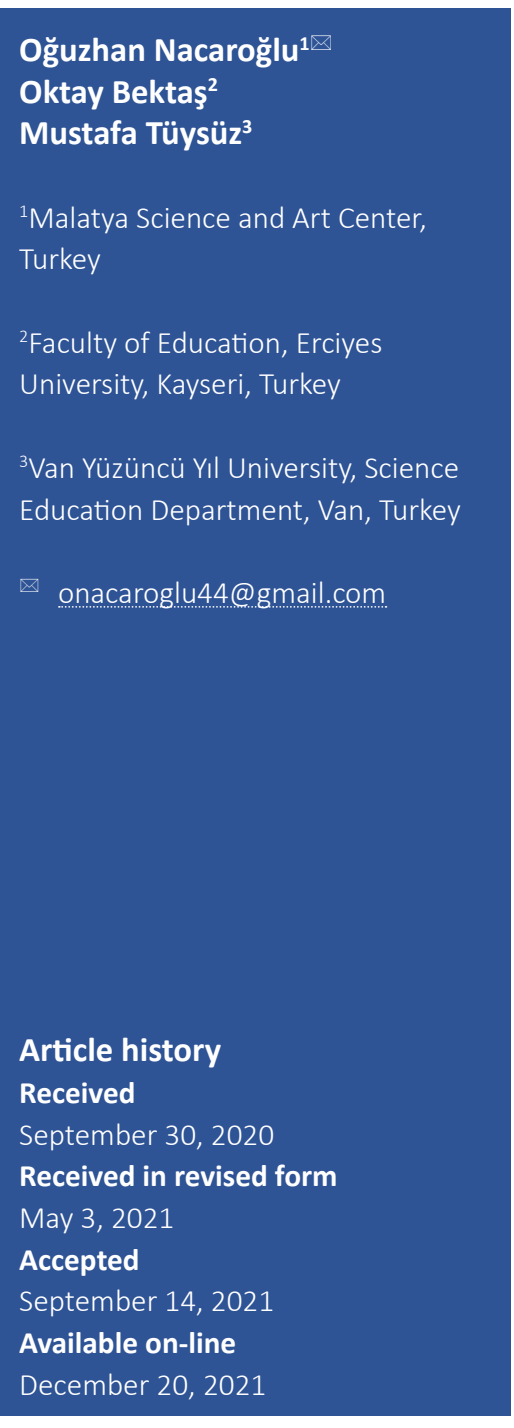

Highlights

- Gifted and non-gifted students have high self-regulation skills towards science.

- There was no statistically significant difference between the average scores of gifted female and male students on the overall scale.

- A statistically significant difference was found between the mean scores of non-gifted female and male participants in the overall scale.

- It was determined that gifted students' self-regulation skills increase as the age gets older while the self-regulation skills of non-gifted students decrease.

- A statistically significant difference in the overall scale was found between gifted and non-gifted students' mean scores in favor of gifted students.

\section{INTRODUCTION}

Today, rapid changes have been taking place in the field of industry and science. As the pioneer of this change, Industry 4.0 industrial revolution affecting individual and social areas have been shown (Vaidya, Ambad and Bhosle, 2018). With the last industrial revolution where machine power has replaced human resources, individuals have become crucial to make radical changes in education to have $21^{\text {st }}$-century skills and to produce and use knowledge (Puncreobutr, 2016). The Industrial 4.0 and production, innovation-oriented Education
4.0 education revolution have made it compulsory for students to develop appropriate learning strategies, learn to maintain their academic goals, and organize their actions towards this purpose (Ciolacu et al. 2017), thus enabling students to have self-regulation skills.

\section{Self-regulation}

The fact that self-regulation, which we encounter particularly in education and neuroscience (McClelland et al. 2018), is cognitively, affectively, and behaviorally versatile, revealing 
different views regarding its dimensions and definition. For example, Kopp (1982) emphasized the behavioral dimension of self-regulation as initiating and maintaining movement according to the situation while Posner and Rothbart (1998) stated the cognitive dimension of self-regulation by defining it as being able to control the desires and orientations of the individual and focusing on the target by maintaining attention. In general, self-regulation, which allows individuals to relate to their environment and control their behaviors by observing themselves, is defined as the processes that students use to activate their emotions and behaviors in line with their goals (Can Aran, 2015; Zimmerman and Kitsantas, 2014). In other words, self-regulation is the capacity of an individual to manage and change his/her ego's responses by controlling innate desires and tendencies (Bauer and Baumeister, 2011). The behavioral theory defines self-regulation as "learned self-control"; in the socio-cultural context, self-regulation is considered within the relationship between the individual and the environment. Since self-regulation includes different dimensions and definitions, it has led to the emergence of other self-regulated learning models.

\section{Self-Regulated Learning Models}

In self-regulatory learning within the scope of the processoriented metacognitive model, an appropriate learning strategy is developed and implemented while considering the performance of the student in accordance with their goals (Borkowski, 1992). Another model is the four-stage selfregulated learning model. This model includes the stages of determining tasks and goals, implementing planning and strategies, and regulating metacognition (Winne and Hadwin, 1998). Another model is adaptive self-regulated learning. The most important stage of this model is the preparation stage in which the student evaluates (Boekaert, 1997). Pintrich's selfregulated learning model, based on social learning theory, examines self-regulation in terms of prediction, monitoring, control, and reflection (cited in Zat, 2018). According to Pintrich et al. (1991), the student should continuously improve himself/herself regarding content, behavior, cognition, and motivation. Zimmerman's approach is based on the Social Cognitive Learning Theory, which was the first to introduce a self-regulated learning model in the literature. This model includes prediction, performance, and self-reflection stages (Zimmerman, 1989).

Regardless of the model, the common point of self-regulation models is to enable students to take responsibility for their own learning, to gain the ability to control and evaluate their behavior in line with their goals (Dembo and Eaton, 2000). Hence, it is crucial for all individuals to have self-regulation skills to adapt to the rapidly changing new world order and control and evaluate their academic lives (Siegle, 2013). It is thought that individuals need to gain self-regulation skills to contribute to the countries gaining an advantageous position with other countries owing to increasing in knowledgeintensity with technological developments (Hilbert, 2014), the emerging of new business areas, and getting of the importance of lifelong learning skills (Chan and Rao 2010). In this context, it is necessary to examine the level of self-regulation skills of individuals in the present century and investigate the underlying reasons for this situation in depth if individuals with low self-regulation skills. For this reason, many countries have been working to identify and develop students' self-regulation skills at all levels of education. Self-regulated learning, which includes a dynamic and complex process by its nature (Muis, Chevrier and Singh, 2018), could be considered to be especially crucial for gifted students with higher level skills than their peers to recognize and improve their interests and abilities (Obergriesser, Steinbach and Stoeger, 2013; Tortop and Eker, 2014).

\section{Gifted Students and Science Self-Regulation Skills}

Gifted students are defined as individuals with high level abilities and competencies in one or more fields (Philips, 2019). Renzulli (1986) discussed the characteristics of gifted students under three headings creativity, being above average in general abilities, and task commitment. These individuals can exhibit many different behaviors in their social and educational lives. Gifted students focus on areas of interest, produce innovative solutions to problems, demonstrate a high level of self-awareness, transfer their knowledge to changing situations, and prefer challenging tasks (Cavilla, 2019; Kutlu Abu, 2018). Additionally, gifted students are shown as the most important human resource for economic and social welfare (Rinn and Bishop, 2015). Due to these characteristics of gifted students, it is necessary for different and challenging educational environments/teaching strategies such as acceleration, enrichment, and deepening (Renzulli and Reis, 2000). Because in the education of these students, suitable school environments are of great importance besides the education in the family (Lipovská and Fischer, 2016).

Heilbronner (2009) suggested that gifted students should be educated in accordance with their learning styles, interests, and needs. These students' curriculum should be organized in a flexible way that allows them to manage their own learning (Hockett, 2009). Otherwise, the teaching activities carried out within a particular program may not contribute to the developing of these students' skills, such as self-regulation, problem-solving, and creativity (Stoltz et al. 2015). In this context, the education of gifted students is carried out in Science and Art Centers (SAC). In SACs, different curriculums are applied to reveal the interests and abilities of gifted students and enable them to use them. In these educational centers, different curriculums have been implemented to demonstrate the interests and skills of gifted students, and allow them to use these skills. These programs are Adaptation Training (AT), Support Training (ST), Individual Talent Recognition (ITR), Special Skill Development (SSD), and Project Production and Management (PPM). It is important that gifted students studying in these centers have the outcomes of the determined courses. One of these courses is the science that attaches importance to individuals' science literacy and $21^{\text {st }}$-century skills.

The science course has general objectives, such as providing students with basic science-related skills, creating social awareness for the sustainability of resources, and understanding the stages of the formation of scientific knowledge and the 
nature of science (Ministry of National Education [MoNE], 2018). In line with this general purpose, it is important that gifted students in science courses should emphasize their scientific literacy, use their skills, and have self-regulatory learning skills by controlling their learning in the SAC. Because it is stated that an individual, who have self-regulation in the science course, is able to hold her/his cognitive processes by being aware of his/her own characteristics, has self-confidence in receiving new information, is also highly motivated in academic studies, and arranges the environments for working efficiently (Montalvo and Torres, 2004; Schunk, 2009). When the literature was examined, it was seen that the number of studies on the self-regulation skills of gifted students was limited. Kutlu Abu (2018) stated that differentiated science activities for the inclusion of gifted students positively improved their motivations and strategies for self-regulation. In addition, Kirişçi (2013) investigated the self-regulated learning and motivational beliefs of non-gifted and gifted students in mathematics. The findings obtained from this research indicated a difference in favor of female students in the use of extrinsic focus, exam anxiety, self-regulation, and cognitive strategy in non-gifted students and only in self-regulation for gifted students.

\section{Purpose of the Study}

Gifted students studying in the same learning environments with their peers face many problems such as managing time, not being able to evaluate their learning, not being able to set goals, and not being aware of their abilities (Stoeger and Ziegler, 2010). Appropriate content studies have been prepared in the SAC to solve these problems experienced by gifted students in having self-regulation skills that include a complex process. In this context, it is essential to examine and compare the gifted and non-gifted students' self-regulation skills in terms of creating appropriate self-regulated learning content for these students. Hence, in this study, it was aimed to investigate the self-regulation skills of gifted and non-gifted students regarding different variables and to compare the selfregulation skills of these students for science. Determining the skill levels of gifted and non-gifted students such as setting goal, developing and applying appropriate learning strategy, time management, effort regulation is thought to help researchers, teachers, experts, and families in terms of preparing suitable curriculum for these students. Because, with the results obtained, it is crucial to examine the students' level of the science self-regulation skills in terms of correct understanding and guidance of students. The research was assumed that gifted and non-gifted students respond sincerely to the items on the scale and that the sample represents the accessible population. One of study's limitations was that the study included non-gifted students and gifted students who continue their education in a SAC in a city in Anatolia. In this context, the following problems were sought:

1. What is the level of self-regulation skills of gifted students towards science?

2. Is there a statistically significant difference between gifted students' science self-regulation skill scores in terms of gender variables?
3. $\mathrm{H}_{0} 1$ : There is no statistically significant difference between gifted students' science self-regulation skill scores in terms of gender variables.

4. Is there a statistically significant difference between gifted students' science self-regulation skill scores in terms of the program variable?

5. $\mathrm{H}_{0} 2$ : There is no statistically significant difference between gifted students' science self-regulation skill scores in terms of the program variable.

6. Is there a statistically significant difference between gifted students' science self-regulation skill scores in terms of different age groups?

7. $\mathrm{H}_{0} 3$ : There is no statistically significant difference between gifted students' science self-regulation skill scores in terms of different age groups.

8. What is the level of self-regulation skills of non-gifted students towards science?

9. Is there a statistically significant difference between nongifted students' science self-regulation skill scores in terms of gender variables?

10. $\mathrm{H}_{0} 4$ : There is no statistically significant difference between non-gifted students' science self-regulation skill scores in terms of gender variables.

11. Is there a statistically significant difference between nongifted students' science self-regulation skill scores in terms of different age groups?

12. $\mathrm{H}_{0} 5$ : There is no statistically significant difference between non-gifted students' science self-regulation skill scores in terms of different age groups.

13. Is there a statistically significant difference between gifted and non-gifted students' science self-regulation skill scores in terms of total and sub-dimensions of the scale?

14. $\mathrm{H}_{0} 6$ : There is no statistically significant difference between gifted and non-gifted students' science selfregulation skill scores in terms of the scores of total and sub-dimensions of the scale.

\section{MATERIALS AND METHODS \\ Research Model}

In this study, it was aimed to seek and compare the selfregulation skills of gifted and non-gifted students towards science. For this purpose, survey research was utilized as a type of quantitative research method design. This design, which purposes to describe the past or present situation, event, opinion, and phenomenon (Büyüköztürk et al. 2010), is the research design carried out on relatively larger samples (Fraenkel and Wallen, 2006).

\section{Population and Sample}

The research sample consisted of 745 students, including 263 gifted students studying at a Science and Art Center and 482 non-gifted students continuing their education in public schools in the Eastern Anatolia Region of Turkey. Moreover, the sample was chosen from the accessible population by using the cluster random sampling. In cluster sampling, the accessible universe is divided into clusters and a sample is created by random selection from the created groups (Creswell and 
Clark, 2016). In this context, the schools where the study was conducted were numbered and five schools were determined by lot to apply the scale to non-gifted students. Demographic information of the participants in the sample obtained by reaching at least $10 \%$ of the accessible population is given in Table 1. Demographic information of the participants in the sample obtained by reaching at least $10 \%$ of the accessible population is provided in Table 1.

\begin{tabular}{|c|c|c|c|c|}
\hline Group & Variables & Demographic information & $f$ & $\%$ \\
\hline \multirow{9}{*}{$\begin{array}{l}\text { Gifted } \\
\text { Students }\end{array}$} & \multirow{2}{*}{ Gender } & Female & 132 & 50.2 \\
\hline & & Male & 131 & 49.8 \\
\hline & \multirow{3}{*}{ Age } & $6-10$ & 110 & 41.8 \\
\hline & & $11-15$ & 120 & 45.6 \\
\hline & & 16 and over & 33 & 12.6 \\
\hline & \multirow{4}{*}{ SAC Program } & Support training & 77 & 29.3 \\
\hline & & Individual Talent Recognition & 74 & 28.1 \\
\hline & & Special Skill Development & 67 & 25.5 \\
\hline & & Project Production and Management & 45 & 17.1 \\
\hline \multirow{5}{*}{$\begin{array}{l}\text { Non-gifted } \\
\text { Students }\end{array}$} & \multirow{2}{*}{ Gender } & Female & 222 & 46.1 \\
\hline & & Male & 260 & 53.9 \\
\hline & \multirow{3}{*}{ Age } & $6-10$ & 195 & 40.5 \\
\hline & & $11-15$ & 190 & 39.4 \\
\hline & & 16 and over & 97 & 20.1 \\
\hline
\end{tabular}

Table 1: Demographic information for participants (source: own calculation)

As seen in Table 1, 50.2\% of the gifted students were female while $49.8 \%$ were male participants. Likewise, $53.9 \%$ of the non-gifted students were male participants and $46.1 \%$ were female participants. Moreover, 77 gifted students continue their education in support education, 74 in individual talent recognition, 67 in special skill development, and 45 in project production and management programs. The ages of all participants ranged from 6 to 18 years.

\section{Data Collection Tools}

The self-regulation scale developed by Pintrich et al. (1991) for university students and called the "Motivated Strategies for Learning Questionnaire" (MSLQ) was utilized as the data collection tool in the study. The scale includes three parts and 81 items, and within the scope of the research, the study was conducted with 50 items of the "self-regulation strategies" section of the scale. While forming the scale, the views of two science educators who are experts in their fields were taken. In this context, the scale prepared in 7-point Likert-type was converted to 5-point Likert-type and arrangements were made in articles 4, 16, 21, 27, 29, 48, and 50 items. For example, Item 29 , which was initially written as "If a subject is difficult, I will either stop working or study the easy parts. ", was changed to "If a science topic is difficult, I will either give up studying or only study the easy parts." in line with the opinions of experts. In this way, the students were enabled to express their views about the science course. Factor analysis was conducted to reveal the theoretical structure of the scale (Pallant, 2016). As a result of the analysis, the Kaiser-Meyer-Olkin [KMO] value was found as.89. According to the exploratory factor analysis outcome, it was decided to collect the scale under eight factors and the determined factors explain $49.25 \%$ of the total variance. Conformity index values were also calculated by conducting confirmatory factor analysis. (Root Mean Square Error of Approximation [RMSEA] $=.045$, Normed Fit Index
$[\mathrm{NFI}]=.93$, Comparative Fit Index $[\mathrm{CFI}]=.97$, Incremental Fit Index $[\mathrm{IFI}]=.97$, Relative Fit Index $[\mathrm{RFI}]=.93$, Goodness of Fit Index $[\mathrm{GFI}]=.95$, Adjusted Goodness of Fit Index $[\mathrm{AGFI}]=.66)$. It could be stated that the obtained indexes were within acceptable ranges and the scale forms a good fit with the determined fit indexes (Schumacker and Lomax, 2004). Sample items under each factor were indicated in Table 2.

As seen in Table 2, the items under each factor were examined and named. When the items in the first factor are concerned, this factor is called "elaboration" because it includes the individual's processes to make the information understandable (Salovaara, 2005). The second factor was named "time regulation". The items under this factor are named in this way because they highlight the time dimension. For example, Item 49, written as "I don't find much time to review my notes or readings before the science exam." emphasizes time regulation. When the items in the third factor are checked, it is named "organizing" since it emphasizes schematization and connection (Wolters, Pintrich and Karabenick, 2003). For example, item 33, written as "While I am reading for a science course, I try to link what I read at the time with my previous knowledge.", is named this way because it involves the individual's organization of mental processes. When the items in the fourth factor were examined, this factor was called "critical thinking". For example, the item 20 in the fourth factor, written as "I consider the topics covered in the science course as a starting point and try to form my own ideas on the relevant topics." draws attention to the individual's ability to present ideas by analyzing their situation. When the items in the fifth factor were checked, this factor was named "effort regulation". Item 10 in the fifth factor, written as "If I am confused about something while reading about the science course, I go back to the beginning and try to understand.", indicates that the individual regulates his/her effort. When the items in the sixth factor were examined, this factor was 
named "help seeking". For instance, the item 37 in this factor, written as "If I cannot understand a topic in a science course, I seek help from another student in the class.", emphasizes seeking help in learning the subject. When the items in the seventh factor were checked, this factor was named "metacognitive self-regulation". The item 47 in this factor, written as "While I study science, I set goals for myself to direct my studies.", evaluates the process of planning and organizing students' learning. When the items in the eighth factor were analyzed, this factor was named "repetition". The item 8 in this factor, written as "While I study science, I repeat important information inside of me over and over again.", includes situations such as underlining the subject and reading it repeatedly.

\begin{tabular}{|c|c|c|c|c|}
\hline Factors & Factor names & $\begin{array}{l}\text { Items in the } \\
\text { factor. }\end{array}$ & $\begin{array}{l}\text { Reliability } \\
\text { coefficient }\end{array}$ & Sample item \\
\hline Factor 1 & Elaboration & $\begin{array}{l}3,5,11,28,32 \\
36,38,40,41,48\end{array}$ & .887 & $\begin{array}{l}\text { While studying in the science class, I review what I have } \\
\text { read and the notes I have taken and try to identify the most } \\
\text { important points. }\end{array}$ \\
\hline Factor 2 & Time regulation & $\begin{array}{l}2,6,9,21,26,29 \\
42,46,49\end{array}$ & .892 & $\begin{array}{l}\text { I often do not have enough time for science because I am } \\
\text { involved in other activities. }\end{array}$ \\
\hline Factor 3 & Organizing & $\begin{array}{l}18,27,30,31 \\
33,34\end{array}$ & .889 & $\begin{array}{l}\text { When I am reading something for science, I try to link what } \\
\text { I am reading with my previous knowledge. }\end{array}$ \\
\hline Factor 4 & Critical thinking & $1,4,7,12,16,20$ & .889 & $\begin{array}{l}\text { I see the topics covered in the science course as a starting } \\
\text { point and try to come up with my own ideas on related } \\
\text { topics. }\end{array}$ \\
\hline Factor 5 & $\begin{array}{l}\text { Effort } \\
\text { regulation }\end{array}$ & $10,22,23,35$ & .888 & $\begin{array}{l}\text { I constantly try to revise my ideas about what I have learned } \\
\text { in the science class. }\end{array}$ \\
\hline Factor 6 & Help seeking & $14,19,37,44$ & .886 & $\begin{array}{l}\text { If I do not understand a subject in science class, I ask for help } \\
\text { from another student in the class. }\end{array}$ \\
\hline Factor 7 & $\begin{array}{l}\text { Meta-cognitive } \\
\text { self-regulation }\end{array}$ & $\begin{array}{l}13,39,43,45 \\
47,50\end{array}$ & .893 & $\begin{array}{l}\text { When I study science, I set goals for myself to direct my } \\
\text { studies. }\end{array}$ \\
\hline Factor 8 & Repetition & $8,15,17,24,25$ & .885 & $\begin{array}{l}\text { When I study for science, I repeat important information } \\
\text { many times. }\end{array}$ \\
\hline
\end{tabular}

Table 2: Determined factors for the scale (source: own calculation)

\section{Data Analysis}

For the statistical analysis of the research, the scale has eight dependent variables due to the sub-dimensions mentioned earlier. Moreover, there are independent variables such as gender, age, and types of curriculum. Therefore, it was considered to use the MANOVA to evaluate the collected data at the beginning of the analysis. However, since the assumptions of MANOVA could not be met, it was decided to utilize the independent sample t-test for the comparison of the gender, and the one-way ANOVA for the comparison of the program and age as independent variables although the type1 error rate increased. These analysis methods, which reveal whether there is a significant difference between the averages compared, do not provide information about the size of the difference. Therefore, the effect size calculation was checked in the present study. The effect size findings revealed how much the independent variable explained the total variance in the dependent variable. While interpreting the effect size, if the calculated effect size value is between .2 and .5 , the effect size is considered "small". Similarly, if the calculated effect size value is between .5 and .8 , the effect size is considered "medium". Finally, if the calculated effect size value is between .8 and 1 the effect size is considered "large" (Cohen, 1988). Moreover, since the rate of type-1 error could increase in multiple analyses, Bonferroni correction was also made to reduce the effect of this situation. The formula (significance level $(\alpha)$ /number of group comparisons) was used for the Bonferroni correction (Vialatte and Cichocki, 2008). As a result, the significance level in the study was determined as $p<.006$. Within the scope of the research, descriptive statistical analysis was conducted by calculating frequency $(f)$, percentage $(\%)$, mean, and standard deviation values to carry out inferential statistics for the scores obtained from the self-regulation scale. To determine whether the scores obtained from the scale differ according to gender, program types and age variable, it was first checked whether the scores were normally distributed for each variable. The determined values were presented in Table 3 (see next page).

When the total scores of the participants obtained from the scale were examined in terms of gender, SAC program types, and age, it was determined that the mean and median values were very close to each other, and the kurtosis and skewness values varied between -1 and +1 . Thus, it could be said that the scores obtained from the scale indicated normal distribution regarding gender, SAC program types, and age (Tabachnick and Fidell, 2013). Finally, independent sample $t$-test for comparison the scores of the participants in terms of gender was chosen, and one-way analysis of variance (ANOVA) was used to compare the scores obtained from the scale regarding the SAC program types and age. "(The number of option-1)/number of options" formula was used to determine the level of participation of gifted and non-gifted students in items of dimensions in the self-regulation scale. Thus, the discontinuous answer choices become continuous and interpret the statistically obtained data facilitated by using this formula. In this context, the score ranges of the science self-regulation scale containing the fivepoint Likert type were given in Table 4. 


\begin{tabular}{|c|c|c|c|c|c|c|c|c|}
\hline Group & Var & & Mean & Median & Skewness & Kurtosis & Min & Max \\
\hline \multirow{9}{*}{$\begin{array}{l}\text { Gifted } \\
\text { Students }\end{array}$} & \multirow{2}{*}{ Gender } & Male & 188.4 & 187.0 & .435 & .025 & 153 & 243 \\
\hline & & Female & 188.9 & 188.5 & .281 & .175 & 135 & 236 \\
\hline & \multirow{4}{*}{ SAC Programs } & ST & 187.4 & 188 & .487 & -.062 & 160 & 235 \\
\hline & & ITR & 187.4 & 187.5 & .219 & -.327 & 153 & 226 \\
\hline & & SSD & 189.8 & 188 & .002 & -.100 & 135 & 235 \\
\hline & & PPM & 191.2 & 189 & .559 & .084 & 155 & 243 \\
\hline & \multirow{3}{*}{ Age } & $6-10$ & 186.5 & 186.5 & .405 & -.123 & 153 & 235 \\
\hline & & $11-15$ & 190.3 & 188 & .218 & .227 & 135 & 243 \\
\hline & & 16 and over & 190.1 & 189 & .420 & .259 & 155 & 238 \\
\hline \multirow{5}{*}{$\begin{array}{l}\text { Non-gifted } \\
\text { Students }\end{array}$} & \multirow{2}{*}{ Gender } & Male & 177.5 & 177 & -.077 & .112 & 108 & 237 \\
\hline & & Female & 184.7 & 186 & .711 & .359 & 88 & 231 \\
\hline & \multirow{3}{*}{ Age } & $6-10$ & 177 & 175 & .447 & -.033 & 88 & 237 \\
\hline & & $11-15$ & 184 & 186 & -.462 & .400 & 120 & 231 \\
\hline & & 16 and over & 182.4 & 182 & -.444 & .032 & 127 & 227 \\
\hline
\end{tabular}

Table 3: Descriptive statistics results of the scale scores (source: own calculation)

\begin{tabular}{ll}
\multicolumn{2}{c}{ Science self-regulation scale } \\
\hline Strongly Disagree & $1.00-1.80$ \\
\hline Disagree & $1.81-2.60$ \\
\hline Neutral & $2.61-3.40$ \\
\hline Agree & $3.41-4.20$ \\
\hline Strongly Agree & $4.21-5.00$ \\
\hline
\end{tabular}

Table 4: The score ranges for scales (source: own calculation)

\section{RESULTS}

\section{Science Self-Regulation Skills of Gifted Students}

Within the scope of the research, the answer of the question "What is the level of science self-regulation skills of gifted students towards science?" was sought. In this context, descriptive statistics findings regarding the scores obtained by gifted students from the overall scale and each dimension were indicated in Table 5.

\begin{tabular}{lll}
\multicolumn{1}{c}{ Self-regulation Scale } & $\boldsymbol{N}$ & $\overline{\boldsymbol{X}}$ \\
\hline Elaboration & 263 & 3.83 \\
\hline Time Regulation & 263 & 3.56 \\
\hline Organizing & 263 & 3.90 \\
\hline Critical Thinking & 263 & 3.76 \\
\hline Effort Regulation & 263 & 3.75 \\
\hline Help Seeking & 263 & 3.83 \\
\hline Meta-cognitive Self-regulation & 263 & 3.91 \\
\hline Repetition & 263 & 3.72 \\
\hline Total Score & 263 & 3.78
\end{tabular}

Table 5: Descriptive Statistics on the Scale Scores of Gifted Students (source: own calculation)

When Table 5 was examined, it was seen that the total score average was found to be 3.78. Therefore, gifted students stated their opinions as Agree with 3.78 degrees of participation in the self-regulation scale. Likewise, the views of the gifted students regarding the sub-dimensions of the scale were examined, the students expressed their opinions as Agree in the sub-dimensions of Elaboration $(\bar{X}=3.83)$, Time regulation $(\bar{X}=3.56)$, Organizing $(\bar{X}=3.37)$, Critical thinking $(\bar{X}=3.76)$, Effort regulation $(\bar{X}=3.75)$, Help-seeking $(\bar{X}=3.83)$, Meta-cognitive selfregulation $(\bar{X}=3.91)$, and Repetition $(\bar{X}=3.72)$. Moreover, it was among the findings that gifted students agreed at least with the items in the Time regulation dimension and the most with the items in the Meta-cognitive self-regulation dimension.

\section{Examination of Science Self-Regulation Skills of Gifted Students in Terms of Gender Variable}

Within the scope of the research, the response of the question "Is there a statistically significant difference between gifted students'science self-regulation skill scores in terms of gender variables?" was sought. In this context, an independent sample 
$t$-test analysis was conducted to examine whether the total mean scores of male and female gifted students in the overall and sub-dimensions of the scale differ significantly. Analysis results were given in Table 6:

\begin{tabular}{|c|c|c|c|c|c|c|c|c|}
\hline Dimension & Gender & $N$ & $\bar{x}$ & $s d$ & $d f$ & $t$ & $p$ & $\begin{array}{l}\text { Effect Size } \\
\qquad\left(\eta^{2}\right)\end{array}$ \\
\hline \multirow{2}{*}{ Elaboration } & Male & 131 & 3.83 & 5.24 & \multirow{2}{*}{261} & \multirow{2}{*}{-1.089} & \multirow{2}{*}{.277} & \multirow{2}{*}{.004} \\
\hline & Female & 132 & 3.86 & 4.66 & & & & \\
\hline \multirow{2}{*}{ Time Regulation } & Male & 131 & 3.60 & 4.03 & \multirow{2}{*}{261} & \multirow{2}{*}{1.419} & \multirow{2}{*}{.157} & \multirow{2}{*}{.007} \\
\hline & Female & 132 & 3.51 & 4.55 & & & & \\
\hline \multirow{2}{*}{ Organizing } & Male & 131 & 3.91 & 3.28 & \multirow{2}{*}{261} & \multirow{2}{*}{.219} & \multirow{2}{*}{.765} & \multirow{2}{*}{.001} \\
\hline & Female & 132 & 3.89 & 3.48 & & & & \\
\hline \multirow{2}{*}{ Critical Thinking } & Male & 131 & 3.80 & 3.32 & \multirow{2}{*}{261} & \multirow{2}{*}{1.110} & \multirow{2}{*}{.268} & \multirow{2}{*}{.004} \\
\hline & Female & 132 & 3.72 & 3.06 & & & & \\
\hline \multirow{2}{*}{ Effort Regulation } & Male & 131 & 3.73 & 2.81 & \multirow{2}{*}{261} & \multirow{2}{*}{-.265} & \multirow{2}{*}{.791} & \multirow{2}{*}{.002} \\
\hline & Female & 132 & 3.76 & 2.75 & & & & \\
\hline \multirow{2}{*}{ Help Seeking } & Male & 131 & 3.84 & 2.36 & \multirow{2}{*}{261} & \multirow{2}{*}{.408} & \multirow{2}{*}{.684} & \multirow{2}{*}{.006} \\
\hline & Female & 132 & 3.81 & 2.27 & & & & \\
\hline \multirow{2}{*}{$\begin{array}{l}\text { Meta-cognitive } \\
\text { Self-regulation }\end{array}$} & Male & 131 & 3.80 & 3.34 & \multirow{2}{*}{261} & \multirow{2}{*}{-2.779} & \multirow{2}{*}{.006} & \multirow{2}{*}{.028} \\
\hline & Female & 132 & 3.96 & 2.87 & & & & \\
\hline Renetition & Male & 131 & 3.70 & 3.21 & & & & \\
\hline Repetition & Female & 132 & 3.73 & 3.27 & 261 & -.406 & .685 & .006 \\
\hline Total Scoro & Male & 131 & 3.76 & 2.33 & 261 & 216 & 806 & (002 \\
\hline lotal score & Female & 132 & 3.77 & 2.26 & 261 & -.246 & .806 & .002 \\
\hline
\end{tabular}

Table 6: Mean, Standard Deviation, $t$ and $p$ Values Regarding Total Scores of Male and Female Gifted Students Participants from SelfRegulation Scale (source: own calculation)

When Table 6 was evaluated, no statistically significant difference $(p>.006, t=-.246)$ was found between the total mean scores of the female and male participants from the scale $\left(\bar{X}_{\text {Female }}=3.77, \bar{X}_{\text {Male }}=3.76\right)$. Moreover, there was not any statistically significant difference between the scores obtained by male and female gifted students from each sub-dimension of the scale $(p>.006)$. Therefore, $\mathrm{H}_{0} 1$ hypothesis was not rejected in terms of all dimensions and total score.

\section{Examination of Science Self-Regulation Skills of Gifted Students Regarding Program Variable}

Within the scope of the research, the answer of the question "Is there a statistically significant difference between gifted students'science self-regulation skill scores in terms of the program variable?" was investigated. One-way analysis of variance (ANOVA), one of the parametric tests, was conducted to response this sub-problem. The group statistics obtained from the analysis was indicated in Table 7.

\begin{tabular}{l|c|c}
\multicolumn{1}{c|}{ Program } & $\boldsymbol{N}$ & $\overline{\boldsymbol{X}}$ \\
\hline Support Training & 77 & 3.74 \\
\hline ITR & 74 & 3.75 \\
\hline SSD & 67 & 3.79 \\
\hline Project Production and Management & 45 & 3.82 \\
\hline Total & 263 & 3.77 \\
\hline
\end{tabular}

Table 7: Descriptive Statistics Results for the Program Variable (source: own calculation)

When Table 7 was analyzed, it was found that the mean of the gifted students enrolled in different SAC program types was close to each other. When the Levene's test results were examined, it was found that the assumption of homogeneity of variances was met for each dimension and scale in general $(p>.05)$. The significance of the differences between the mean scores of the general and sub-dimensions of the scale was analyzed by using ANOVA. The results were given in Table 8 . In Table 8 , it was seen that No significant difference was found between the averages obtained from both the general $[F(3-259)=.614 ; p>.006]$ and sub-dimensions of the scale in terms of SAC program types $(p>.006)$. Therefore, $\mathrm{H}_{0} 2$ hypothesis was not rejected in terms of all dimensions and total score.

\section{Examination of Science Self-Regulation Skills of Gifted Students Regarding Age Variable}

Within the aim of the research, the response of the question "Is there a statistically significant difference between gifted students' science self-regulation skill scores in terms of different age groups?" was investigated. One-way analysis of variance (ANOVA), one of the parametric tests, was utilized to respond to this sub-problem. The group statistics obtained from the analysis was shown in Table 9. 


\begin{tabular}{|c|c|c|c|c|c|c|c|}
\hline Dimensions & Source Variance & Sum of Squares & $d f$ & $\begin{array}{l}\text { Mean of } \\
\text { Squares }\end{array}$ & $\boldsymbol{F}$ & $p$ & $\begin{array}{c}\text { Effect Size } \\
\left(\eta^{2}\right)\end{array}$ \\
\hline \multirow{3}{*}{ Elaboration } & Between Groups & 66.041 & 3 & 22.014 & \multirow{3}{*}{.892} & \multirow{3}{*}{.446} & \multirow{3}{*}{.010} \\
\hline & Within Groups & 6392.917 & 259 & 24.683 & & & \\
\hline & Total & 6458.958 & 262 & & & & \\
\hline \multirow{3}{*}{ Time Regulation } & Between Groups & 3.738 & 3 & 1.246 & \multirow{3}{*}{.066} & \multirow{3}{*}{.978} & \multirow{3}{*}{.007} \\
\hline & Within Groups & 4868.954 & 259 & 18.799 & & & \\
\hline & Total & 4872.692 & 262 & & & & \\
\hline \multirow{3}{*}{ Organizing } & Between Groups & 56.500 & 3 & 18.833 & \multirow{3}{*}{1.662} & \multirow{3}{*}{.176} & \multirow{3}{*}{.010} \\
\hline & Within Groups & 2935.150 & 259 & 11.333 & & & \\
\hline & Total & 2991.650 & 262 & & & & \\
\hline \multirow{3}{*}{ Critical Thinking } & Between Groups & 18.558 & 3 & 6.186 & \multirow{3}{*}{.601} & \multirow{3}{*}{.615} & \multirow{3}{*}{.006} \\
\hline & Within Groups & 2665.092 & 259 & 10.290 & & & \\
\hline & Total & 2683.650 & 262 & & & & \\
\hline \multirow{3}{*}{ Effort Regulation } & Between Groups & 33.313 & 3 & 11.104 & \multirow{3}{*}{1.440} & \multirow{3}{*}{.231} & \multirow{3}{*}{.016} \\
\hline & Within Groups & 1996.687 & 259 & 7.709 & & & \\
\hline & Total & 2030.000 & 262 & & & & \\
\hline \multirow{3}{*}{ Help Seeking } & Between Groups & 10.688 & 3 & 3.563 & \multirow{3}{*}{.662} & \multirow{3}{*}{.576} & \multirow{3}{*}{.007} \\
\hline & Within Groups & 1392.841 & 259 & 5.378 & & & \\
\hline & Total & 1403.529 & 262 & & & & \\
\hline \multirow{3}{*}{$\begin{array}{l}\text { Meta-cognition } \\
\text { Self-regulation }\end{array}$} & Between Groups & 12.653 & 3 & 4.218 & \multirow{3}{*}{.420} & \multirow{3}{*}{.739} & \multirow{3}{*}{.004} \\
\hline & Within Groups & 2603.560 & 259 & 10.052 & & & \\
\hline & Total & 2616.213 & 262 & & & & \\
\hline \multirow{3}{*}{ Repetition } & Between Groups & 13.836 & 3 & 4.612 & \multirow{3}{*}{.436} & \multirow{3}{*}{.728} & \\
\hline & Within Groups & 2741.244 & 259 & 10.584 & & & .005 \\
\hline & Total & 2755.080 & 262 & & & & \\
\hline & Between Groups & 623.250 & 3 & 207.750 & & & \\
\hline Total & Within Groups & 87585.207 & 259 & 338.167 & .614 & .606 & .007 \\
\hline & Total & 88208.456 & 262 & & & & \\
\hline
\end{tabular}

Table 8: Results of ANOVA Statistics (source: own calculation)

\begin{tabular}{c|c|c} 
Age & $\boldsymbol{N}$ & $\overline{\boldsymbol{X}}$ \\
\hline $6-10$ & 110 & 3.73 \\
\hline $11-15$ & 120 & 3.80 \\
\hline 16 and over & 33 & 3.96 \\
\hline Total & 260 & 3.77
\end{tabular}

Table 9: Results of Descriptive Statistics Related to Age Variable (source: own calculation)

According to Table 9, it was found that the mean of gifted students in different age groups was close to each other. When the Levene's test results were checked, it was seen that the assumption of homogeneity of variances was met for each dimension and scale in general $(p>.05)$. The significance of the differences between the scores obtained from the general and sub-dimensions of the scale was evaluated by utilizing ANOVA. The findings were depicted in Table 10.

When Table 10 was examined, there were not any a significant difference between the averages obtained from both the general $[F(2-260)=.264 ; p>.006]$ and sub-dimensions of the scale in terms of age group $(p>.006)$. Therefore, $\mathrm{H}_{0} 3$ hypothesis was not rejected in terms of all dimensions and total score.

\section{Science Self-Regulation Skills of Non-Gifted Students}

Within the scope of the research, the answer of the question
"What is the level of self-regulation skills of non-gifted students towards science?" was sought. In this context, the findings of the descriptive statistics regarding the scores obtained by non-gifted students from the general and sub-dimensions of the scale were given in Table 11.

When Table 11 was examined, the mean scale was also found to be 3.68. Therefore, non-gifted students stated their opinions as "Agree" with 3.68 degrees of participation in the whole scale. Likewise, the views of the non-gifted students regarding the subdimensions of the scale were investigated, the students express their views as "Agree" in the sub-dimensions of Elaboration $(\bar{X}=3.8)$, Organizing $(\bar{X}=3.70)$, Critical thinking $(\bar{X}=3.91)$, Effort regulation $(\bar{X}=3.98)$, Help-seeking $(\bar{X}=3.55)$, Metacognitive self-regulation $(\bar{X}=3.93)$, and Repetition $(\bar{X}=3.89)$. Moreover, it was determined that non-gifted students agreed with Effort regulation dimension items the most and the items in the Time regulation dimension the least. 


\begin{tabular}{|c|c|c|c|c|c|c|c|}
\hline Dimensions & Source of Variance & Sum of Squares & $d f$ & $\begin{array}{l}\text { Mean of } \\
\text { Squares }\end{array}$ & $\boldsymbol{F}$ & $p$ & $\begin{array}{c}\text { Effect Size } \\
\left(\eta^{2}\right)\end{array}$ \\
\hline \multirow{3}{*}{ Elaboration } & Between Groups & 64.594 & 2 & 32.297 & \multirow{3}{*}{1.313} & \multirow{3}{*}{.271} & \multirow{3}{*}{.010} \\
\hline & Within Groups & 6394.364 & 260 & 24.594 & & & \\
\hline & Total & 6458.958 & 262 & & & & \\
\hline \multirow{3}{*}{ Time Regulation } & Between Groups & 14.107 & 2 & 7.054 & \multirow{3}{*}{.377} & \multirow{3}{*}{.686} & \multirow{3}{*}{.002} \\
\hline & Within Groups & 4858.585 & 260 & 18.687 & & & \\
\hline & Total & 4872.692 & 262 & & & & \\
\hline \multirow{3}{*}{ Organizing } & Between Groups & 8.102 & 2 & 4.051 & \multirow{3}{*}{.353} & \multirow{3}{*}{.703} & \multirow{3}{*}{.002} \\
\hline & Within Groups & 2983.548 & 260 & 11.475 & & & \\
\hline & Total & 2991.650 & 262 & & & & \\
\hline \multirow{3}{*}{ Critical Thinking } & Between Groups & 16.198 & 2 & 8.099 & \multirow{3}{*}{.789} & \multirow{3}{*}{.455} & \multirow{3}{*}{.006} \\
\hline & Within Groups & 2667.452 & 260 & 10.259 & & & \\
\hline & Total & 2683.650 & 262 & & & & \\
\hline \multirow{3}{*}{ Effort Regulation } & Between Groups & 23.782 & 2 & 11.891 & \multirow{3}{*}{1.541} & \multirow{3}{*}{.216} & \multirow{3}{*}{.011} \\
\hline & Within Groups & 2006.218 & 260 & 7.716 & & & \\
\hline & Total & 2030.000 & 262 & & & & \\
\hline \multirow{3}{*}{ Help Seeking } & Between Groups & 3.816 & 2 & 1.908 & \multirow{3}{*}{.354} & \multirow{3}{*}{.702} & \multirow{3}{*}{.002} \\
\hline & Within Groups & 1399.712 & 260 & 5.384 & & & \\
\hline & Total & 1403.529 & 262 & & & & \\
\hline \multirow{3}{*}{$\begin{array}{l}\text { Meta-cognition } \\
\text { Self-regulation }\end{array}$} & Between Groups & 10.542 & 2 & 5.271 & \multirow{3}{*}{.526} & \multirow{3}{*}{.592} & \multirow{3}{*}{.004} \\
\hline & Within Groups & 2605.670 & 260 & 10.022 & & & \\
\hline & Total & 2616.213 & 262 & & & & \\
\hline \multirow{3}{*}{ Repetition } & Between Groups & 48.946 & 2 & 24.473 & \multirow{3}{*}{2.351} & \multirow{3}{*}{.097} & \\
\hline & Within Groups & 2706.134 & 260 & 10.408 & & & .017 \\
\hline & Total & 2755.080 & 262 & & & & \\
\hline & Between Groups & 898.929 & 2 & 449.465 & & & \\
\hline Total Score & Within Groups & 87309.527 & 260 & 335.806 & 1.338 & .264 & .010 \\
\hline & Total & 88208.456 & 262 & & & & \\
\hline
\end{tabular}

Table 10: Results of ANOVA Statistics (source: own calculation)

\begin{tabular}{|c|c|c|}
\hline Self-regulation Scale & $N$ & $\bar{x}$ \\
\hline Elaboration & 482 & 3.81 \\
\hline Time Regulation & 482 & 2.72 \\
\hline Organizing & 482 & 3.70 \\
\hline Critical Thinking & 482 & 3.91 \\
\hline Effort Regulation & 482 & 3.98 \\
\hline Help Seeking & 482 & 3.55 \\
\hline Meta-cognitive Self-regulation & 482 & 3.93 \\
\hline Repetition & 482 & 3.89 \\
\hline Total Score & 482 & 3.68 \\
\hline
\end{tabular}

Table 11: Descriptive Statistics on Self-Regulation Scale (source: own calculation)

\section{Examination of Science Self-Regulation Skills of Non-Gifted students in Regarding Gender Variable}

Within the scope of research, the response of the question "Is there a statistically significant difference between non-gifted students' science self-regulation skill scores in terms of gender variables? was investigated. In this context, an independent sample $t$ test analysis was utilized to examine whether male and female non-gifted students' total mean scores obtained from the scale and its sub-dimensions differ significantly. Analysis findings were shown in Table 12.

As seen in Table 12, there is a statistically significant difference $(p<.006, t=-3.776)$ between the total scores of the female and male participants $\left(\bar{X}_{\text {Female }}\right.$ participants $=3.69$ and $\bar{X}_{\text {Male }}$ participants $=3.55) . \mathrm{H}_{0} 4$ hypothesis was rejected in terms of total score. However, since the calculated effect size $\left(\eta^{2}=.028\right)$ is smaller than the value between .2 and .5 , the difference in selfregulation scores in favor of female students has not practical significance and not generalizable to the population. Moreover, there are a significant difference between the scores obtained by the male and female participants from the sub-dimensions of Elaboration $[t(480)=-4.384 ; p<.006]$, Time regulation $[t(480)=2.860 ; p<.006]$, Effort regulation $[t(480)=-4.131$; $p<.006]$, Help seeking $[t(480)=-3.371 ; p<.006]$, Meta-cognitive Self-regulation $[t(480)=-3.770 ; p<.006]$, and Repetition $[t(480)=-3.802 ; p<.006]$. Although, $\mathrm{H}_{0} 4$ hypothesis was rejected 
in terms of sub- dimensions, the difference in self-regulation scores in favor of female students in all sub-dimensions has not a practical significance and cannot be generalized to the accessible population since the calculated effect sizes for the sub-dimensions are smaller than the value between .2 and .5 . Another result obtained from the analysis was that there was no significant difference between the scores obtained from the Organization $[t(480)=-1.961 ; p>.006]$ and Critical Thinking $[t(480)=-2.248 ; p>.006]$.

\begin{tabular}{|c|c|c|c|c|c|c|c|c|}
\hline Dimensions & Gender & $N$ & $\bar{x}$ & $s d$ & $d f$ & $\boldsymbol{t}$ & $p$ & $\begin{array}{c}\text { Effect Size } \\
\qquad\left(\eta^{2}\right)\end{array}$ \\
\hline \multirow{2}{*}{ Elaboration } & Male & 260 & 3.67 & 6.24 & \multirow{2}{*}{480} & \multirow{2}{*}{-4.384} & \multirow{2}{*}{$<.001$} & \multirow{2}{*}{.038} \\
\hline & Female & 222 & 3.93 & 6.31 & & & & \\
\hline \multirow{2}{*}{ Time Regulation } & Male & 260 & 2.77 & 6.18 & \multirow{2}{*}{480} & \multirow{2}{*}{2.860} & \multirow{2}{*}{.004} & \multirow{2}{*}{.016} \\
\hline & Female & 222 & 2.58 & 6.87 & & & & \\
\hline \multirow{2}{*}{ Organizing } & Male & 260 & 3.63 & 4.06 & \multirow{2}{*}{480} & \multirow{2}{*}{-1.961} & \multirow{2}{*}{.060} & \multirow{2}{*}{.007} \\
\hline & Female & 222 & 3.76 & 4.31 & & & & \\
\hline \multirow{2}{*}{ Critical Thinking } & Male & 260 & 3.84 & 3.90 & \multirow{2}{*}{480} & \multirow{2}{*}{-2.248} & \multirow{2}{*}{.065} & \multirow{2}{*}{.010} \\
\hline & Female & 222 & 3.97 & 3.61 & & & & \\
\hline \multirow{2}{*}{ Effort Regulation } & Male & 260 & 3.84 & 2.92 & \multirow{2}{*}{480} & \multirow{2}{*}{-4.131} & \multirow{2}{*}{$<.001$} & \multirow{2}{*}{.034} \\
\hline & Female & 222 & 4.11 & 2.60 & & & & \\
\hline \multirow{2}{*}{ Help Seeking } & Male & 260 & 3.43 & 3.34 & \multirow{2}{*}{480} & \multirow{2}{*}{-3.371} & \multirow{2}{*}{.001} & \multirow{2}{*}{.023} \\
\hline & Female & 222 & 3.69 & 3.45 & & & & \\
\hline \multirow{2}{*}{$\begin{array}{l}\text { Meta-cognitive Self- } \\
\text { regulation }\end{array}$} & Male & 260 & 3.81 & 3.76 & \multirow{2}{*}{480} & \multirow{2}{*}{-3.770} & \multirow{2}{*}{$<.001$} & \multirow{2}{*}{.028} \\
\hline & Female & 222 & 4.03 & 3.84 & & & & \\
\hline Repetition & Male & 260 & 3.76 & 3.59 & & -3.802 & $<.001$ & 029 \\
\hline Rереппо & Female & 222 & 4.00 & 3.02 & 480 & $-3.80<$ & $<.001$ & $.0 \angle 9$ \\
\hline Total Score & Male & 260 & 3.55 & 2.62 & 480 & -3.776 & $<001$ & 028 \\
\hline . fular scute & Female & 222 & 3.69 & 2.63 & 480 & -3.110 & $<.001$ & $.0<0$ \\
\hline
\end{tabular}

Table 12: Mean, Standard Deviation, $t$ and $p$ Values Regarding Total Scores of Male and Female Participants from Self-Regulation Scale (source: own calculation)

\section{Examination of Science Self-Regulation Skills of} Non-Gifted Students Regarding Age Variable

Within the scope of the research, the answer of the question "Is there a statistically significant difference between nongifted students' science self-regulation skill scores in terms of different age groups?" was sought. One-way analysis of variance (ANOVA), one of the parametric tests, was used to analyze this sub-problem. The group statistics obtained from the analysis was indicated in Table 13.

\begin{tabular}{l|c|c}
\multicolumn{1}{c|}{ Age } & $\mathbf{N}$ & $\overline{\boldsymbol{X}}$ \\
\hline $6-10$ & 195 & 3.54 \\
\hline $11-15$ & 190 & 3.68 \\
\hline 16 and over & 97 & 3.64 \\
\hline Total & 482 & 3.61 \\
\hline
\end{tabular}

Table 13: Results of Descriptive Statistics Related to Age Variable (source: own calculation)

When Table 13 was examined, it was seen that there was a difference between the mean scores of non-gifted students in different age groups from the overall scale. When the Levene's test results were evaluated, it was found that the assumption of homogeneity of variances was met for each dimension and scale in general $(p>.05)$. The significance of the differences between the scores obtained from the general and subdimensions of the scale was analyzed by using ANOVA. The results were shown in Table 14.

As seen in Table 14, there was a significant difference between the total scores obtained from the scale in terms of age variable $[F(2-479)=6.669 ; p<.006]$. Moreover, a statistically significant difference was found between the scores obtained for the sub-dimensions of Elaboration $[F(2-479)=9.961$; $p<.006]$, Effort regulation $[F(2-479)=6.342 ; p<.006]$, Help seeking $[F(2-479)=5.725 ; p<.006]$, and Metacognitive Selfregulation $[F(2-479)=7.700 ; p<.006]$. Post Hoc test (LSD) was used to determine the source of the difference. In this context, it was determined that the mean scores of the 11-15 age group for the elaboration, effort regulation, and Metacognitive Self-regulation subscales were higher than the mean scores of the participants in the other age range. Another finding was that mean scores of the sub-dimension of Help seeking were determined to be higher in the 6-10 age range than the mean scores of the participants in the other age range.

$\mathrm{H}_{0} 5$ hypothesis was rejected in terms of total score. However, since the calculated effect size $\left(\eta^{2}=.023\right)$ is smaller than the value between .2 and .5 , the difference has not practical significance and not generalizable to the population. Although, $\mathrm{H}_{0} 5$ hypothesis was rejected in terms of sub-dimensions, the difference in all sub-dimensions has not a practical significance, and cannot be generalized to the accessible population since the calculated effect sizes for the sub-dimensions are smaller than the value between .2 and .5 .

\section{Science Self-Regulation Skills of Gifted and Non-Gifted students}

Within the scope of the research, the answer of the question "Is there a statistically significant difference between gifted and non-gifted students' science self-regulation skill scores in 
terms of total and sub-dimensions of the scale?" was sought. groups was examined separately regarding each dimension. In this comparison, the level of self-regulation skills of the two The results obtained were given in Table 15.

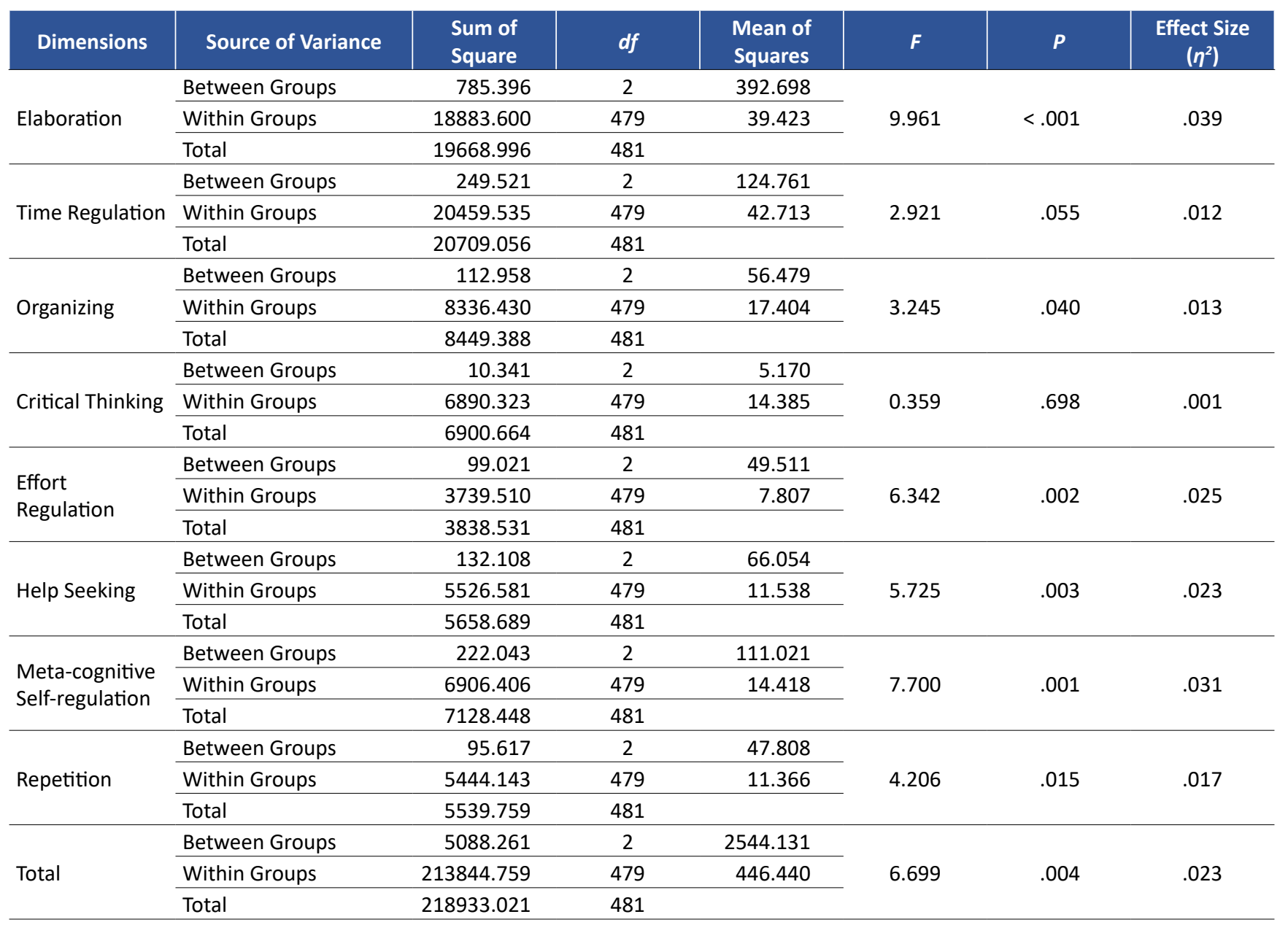

Table 14: Results of ANOVA Statistics (source: own calculation)

\begin{tabular}{|c|c|c|c|c|c|c|c|c|}
\hline Dimensions & Development Level & $N$ & $\bar{x}$ & $s$ & $s d$ & $t$ & $\boldsymbol{P}$ & $\begin{array}{c}\text { Effect Size } \\
\qquad\left(\eta^{2}\right)\end{array}$ \\
\hline \multirow{2}{*}{ Elaboration } & Non-Gifted & 482 & 3.79 & 6.39 & \multirow{2}{*}{657} & \multirow{2}{*}{0.972} & \multirow{2}{*}{.332} & \multirow{2}{*}{.001} \\
\hline & Gifted & 263 & 3.83 & 4.96 & & & & \\
\hline \multirow{2}{*}{ Time Regulation } & Non-Gifted & 482 & 2.68 & 6.56 & \multirow{2}{*}{717} & \multirow{2}{*}{19.601} & \multirow{2}{*}{$<.001$} & \multirow{2}{*}{.340} \\
\hline & Gifted & 263 & 3.55 & 4.31 & & & & \\
\hline \multirow{2}{*}{ Organizing } & Non-Gifted & 482 & 3.69 & 4.19 & \multirow{2}{*}{640} & \multirow{2}{*}{4.397} & \multirow{2}{*}{$<.001$} & \multirow{2}{*}{.025} \\
\hline & Gifted & 263 & 3.90 & 3.37 & & & & \\
\hline \multirow{2}{*}{ Critical Thinking } & Non-Gifted & 482 & 3.90 & 3.78 & \multirow{2}{*}{618} & \multirow{2}{*}{-3.134} & \multirow{2}{*}{.002} & \multirow{2}{*}{.013} \\
\hline & Gifted & 263 & 3.76 & 3.20 & & & & \\
\hline \multirow{2}{*}{ Effort Regulation } & Non-Gifted & 482 & 3.96 & 2.78 & \multirow{2}{*}{545} & \multirow{2}{*}{-4.081} & \multirow{2}{*}{$<.001$} & \multirow{2}{*}{.021} \\
\hline & Gifted & 263 & 3.75 & 2.82 & & & & \\
\hline \multirow{2}{*}{ Help Seeking } & Non-Gifted & 482 & 3.55 & 3.42 & \multirow{2}{*}{710} & \multirow{2}{*}{5.214} & \multirow{2}{*}{$<.001$} & \multirow{2}{*}{.035} \\
\hline & Gifted & 263 & 3.83 & 2.31 & & & & \\
\hline \multirow{2}{*}{$\begin{array}{l}\text { Meta-cognitive Self- } \\
\text { regulation }\end{array}$} & Non-Gifted & 482 & 3.89 & 3.84 & \multirow{2}{*}{632} & \multirow{2}{*}{-0.482} & \multirow{2}{*}{.630} & \multirow{2}{*}{.003} \\
\hline & Gifted & 263 & 3.91 & 3.15 & & & & \\
\hline Benetition & Non-Gifted & 482 & 3.72 & 3.24 & 559 & 3090 & בח & 012 \\
\hline & Gifted & 263 & 3.87 & 3.39 & 559 & -3.090 & .002 & .012 \\
\hline Total Croro & Non-Gifted & 482 & 3.61 & 2.66 & & 5210 & -001 & 035 \\
\hline Total Score & Gifted & 263 & 3.77 & 2.29 & 610 & 5.248 & $<.001$ & .035 \\
\hline
\end{tabular}

Table 15: Independent sample t-test results of science self-regulation skills of gifted and non-gifted students (source: own calculation) 
As seen in Table 15, a statistically significant difference was found in favor of gifted students $(p<.006, t=5.248)$ between the total scores of the gifted and non-gifted students $\left(\bar{X}_{\text {gifted }}=3.77, \bar{X}_{\text {non-gifted }}=3.61\right)$. On the other hand, although there was not any a statistical difference between the mean of the Elaboration and Meta-cognitive self-regulation subdimensions of the gifted and non-gifted participants in the scale, a significant difference was also found between the scores obtained in the other sub-dimensions of the scale in terms of development level. This difference was in favor of gifted students in the dimensions of Time regulation, Organizing, Help seeking, and Repetition whilst it was in favor of non-gifted students in Critical thinking and Effort regulation dimensions. $\mathrm{H}_{0} 6$ hypothesis was rejected in terms of total score. However, since the calculated effect size $\left(\eta^{2}=.035\right)$ is smaller than the value between .2 and .5 , the difference has not practical significance and not generalizable to the population. Although, $\mathrm{H}_{0} 6$ hypothesis was rejected in terms of the sub- dimensions, the difference in all sub-dimensions except that time regulation has not a practical significance, and cannot be generalized to the accessible population since the calculated effect sizes for the sub-dimensions are smaller than the value between .2 and .5. The significant difference in time regulation in favor of gifted students has practical significance and generalizable to the population since the calculated effect size for this subdimension (.340) are bigger than .2. Therefore, this result has a small effect on the population.

\section{DISCUSSION}

The study aimed to examine the self-regulation skills of gifted and non-gifted students towards science. In this context, 745 students, consisting of 263 gifted students continuing in different programs in SAC, and 482 nongifted students attending public schools, participated in the study. Gifted students expressed their views as "Agree" with 3.78 participation degrees on the whole science selfregulation scale. Similarly, the non-gifted students stated their views as "Agree" with 3.68 degrees of participation. Hence, it could be interpreted that gifted and non-gifted students have high self-regulation skills towards science. Gifted students participated the most in the items in the Meta-cognitive self-regulation dimension and the least in the items in the Time regulation dimension. Non-gifted students, on the other hand, participated most in the items in the Effort regulation dimension and the least in the items in the Time regulation dimension like gifted students. This result was different from the results obtained from some investigations (Akpınar, Batdı and Dönder, 2013; Çekim and Aydın, 2018). For example, Çekim and Aydın (2018) in their research with non-gifted students stated that they mostly used the resource management and the Help seeking in the form of "determining who to get help from when they need help in the Science course". In this research, gifted students were more involved in the item "I try to identify the concepts that I do not understand well while studying the science course" in the Metacognitive self-regulation dimension. This finding is similar to the investigation by
Tanti et al. (2020). Meta-cognitive self-regulation, which emphasizes awareness of strategies, resources, and skills to fulfill certain jobs and tasks (Noushad, 2008), involves the process of planning and organizing students' learning (Uzuntiryaki Kondakçı and Aydın Çapa, 2013). Therefore, it is crucial for gifted students to participate in the items in the Meta-cognitive self-regulation dimension in terms of determining their goals, planning their learning, evaluating, and organizing learning processes (Boekaerts and Niemivirta, 2005). Supporting this situation, Li et al. (2018) stated that students with metacognitive self-regulation set higher-level goals such as deep learning in science learning. In addition, more concrete data could be obtained by observing students' metacognitive self-regulation skills with a longitudinal study (Maloney, Ryan and Ryan, 2021). On the other hand, the reasons underlying the fact that both gifted and non-gifted students attend the items in the Time regulation dimension at least should be examined.

Gifted students, who constitute the crucial human resource of societies, should attach importance to time management in their learning process. Because self-regulated learning is a gradual and complex process with emotional, motivational and social components that involves students not only with the academic success achieved in school life, but also to produce realistic and lasting solutions to problems that can be experienced in every moment of life (Çokçalışkan, 2019; Oppong, Shore and Muis, 2019). Therefore, it is important to investigate the reasons and solutions for the low level of participation of gifted and non-gifted students in the time regulation dimension compared to the other dimensions. In this context, it is necessary to implement self-reflective learning practices in formal and informal learning environments (Patrick, 2017; Schunk and Zimmerman, 1998). Having self-reflection skills related to monitoring behaviour and feedback of learning evaluation allows students to manage their time by observing their own learning process and evaluating their learning (Grant, Franklin and Langford, 2002; Moeder-Chandler, 2020).

It was concluded that there was no statistically significant difference between the total mean scores of the science selfregulation scales of the gifted male and female students. This situation was expected in terms of gender equality. There were investigations in the literature that support this finding (Maloney, Ryan and Ryan, 2021; Gröpel, Baumeister and Beckmann, 2014). However, a statistically significant difference was found between the total mean scores of non-gifted male and female participants on the scale. A significant difference was also determined between the scores obtained from the sub-dimensions of Elaboration, Time regulation, Effort regulation, Help seeking, Metacognitive self-regulation, and Repetition in terms of gender variable. The results show differences from some studies (Alc1 and Altun, 2007; Bouffard et al. 1995; Ilgaz, 2011; Lee, 2002; Lynch, 2010), and similarity with some studies (Betül-Cebesoy, 2013; Çalışkan and Sezgin Selçuk, 2010; Hargittai and Shafer, 2006; Tezel Şahin, 2015; Yükseltürk and Bulut, 2009). For example, Betül Cebesoy (2013) stated that the pre-service teachers' motivational and learning 
strategies did not change in terms of gender in the study that investigated the self-regulation skills of participants for physics lesson; Lee (2002), on the other hand, found that female students had more difficulties in self-regulated learning environments. In this respect, researchers should have more qualitative and mixed studies investigating the reasons for the level and differences of students' selfregulation skills in terms of gender.

Another finding was that there was not any significant difference between the total score averages of the gifted students obtained from the overall scale in terms of the SAC program types. Although there was no statistically significant difference, it was found that the average score of the gifted students in the project production and management program was higher than the mean of the students in the other programs. From this point of view, it might be interpreted that the gifted students who continue to the SAC have increased their level of self-regulation skills towards science as they move on to the next program. Particularly, the reason for the high self-regulation skills of the students in the project production and management program is high because of the creation of the learning environments necessary for the gifted students enrolling this program to participate in national and international project competitions and to organize their learning in this process by experienced advisors (Powers, 2008). It was also thought that doing science-based projects in these institutions could be effective (Chiang and Lee, 2016; Girgin, 2020). Another finding of the study was that although there is no significant difference between the total score averages of gifted students in different age groups obtained from the overall scale, it was found that the average score of 16 and over participants was higher than the average score of individuals in the other age group. Since the individuals in this age range are individuals in the project production and management program, this result supports the high self-regulation skills of the students in the project production and management program. Therefore, this situation shows that activities are carried out in SACs to enhance the self-regulation skills of the students, especially in the project production and management program. This result is different from nongifted students.

It was concluded that the self-regulation skills of gifted students increased as the age progressed while non-gifted students decreased. A statistically significant difference was found between the scores of non-gifted students in general of the scale and the sub-dimensions of Elaboration, Effort regulation, Help-seeking, and Meta-cognitive self-regulation regarding the age variable. In addition, participants between the ages of 11-15; It was concluded that the mean scores of the Elaboration and Effort regulation sub-dimensions were higher than the average scores of the participants in the other age range. In the emergence of this situation, it might be said that suitable environments have been created for individuals in the age range with high self-regulation skills to organize and evaluate their own learning. Moreover, as the age gets older, exam-oriented studies might have caused to decrease their self-regulation skills. For example, in the current study, while the gifted students attending the SAC organized their learning by only doing scientific and artistic learning without exam anxiety, the non-gifted students did examoriented studies in their schools. This situation could be considered the reason for the decline in non-gifted students' self-regulation skills as they get older because it was stated that performance-oriented behavioral measures decrease self-regulation skills (Parlak Y1lmaz, 2005). Furthermore, insufficient time and equipment of teachers to use learning strategies is shown among the factors that prevent students from developing self-regulation skills (Zumbrunn, Tadlock and Roberts, 2011). These factors prevent students from achieving their goals and cause them to fail to monitor and evaluate themselves (Baumeister, Heatherton and Tice, 1994). Considering the factors that hinder self-regulation skills, it explains the higher self-regulation skills of gifted students in science compared to non-gifted students. The findings obtained in this context support this conclusion.

This study is quantitative research, and more in-depth findings of students' self-regulation skills can be obtained by conducting different studies using qualitative research designs. Moreover, the self-regulation skills of non-gifted and gifted students might be improved with a studentcentered learning method by conducting experimental studies.

\section{CONCLUSION}

It was concluded that gifted and non-gifted students had high science self-regulation skills. Moreover, gifted students mostly participated in the metacognitive self-regulation dimension and non-gifted students in the effort regulation dimension. On the other hand, students in both groups participated least in the time regulation dimension. Although there was no statistically significant difference between male and female gifted students' mean scores, there was a statistically significant difference between the mean scores of non-gifted female and male participants. Furthermore, it was seen that there was no significant difference between the mean scores of the gifted students in the different program types. On the other hand, researchers concluded that as gifted students get older, their self-regulation skills increase while non-gifted students' selfregulation skills decrease. A statistically significant difference was found in favor of gifted students in terms of the selfregulation skills. In addition, although there was no statistically significant difference between the mean scores of gifted and non-gifted students in terms of elaboration and metacognitive self-regulation, a significant difference was found between the mean scores in the other sub-dimensions of the scale. Whilst this difference was in favor of gifted students in the Time regulation, Organizing, Help seeking, Meta-cognitive Selfregulation, and Repetition dimensions, it favored non-gifted students in Critical thinking and Effort regulation dimensions. 
Akpınar, B., Batdı, V. and Dönder, A. (2013) 'Evaluating Primary School Students' Motivation Levels in Science Education in Terms of Gender and Class Variables', Cumhuriyet International Journal of Education, Vol. 2, No. 1, pp. 15-26.

Alc1, B. and Altun, S. (2007) 'Lise Öğrencilerinin Matematik Dersine Yönelik Özdüzenleme ve Bilişüstü Becerileri, Cinsiyete, Sınıfa ve Alanlara göre Farklılaşmakta mıdır? [Do High School Students' Self-regulation and Metacognitive Skills for Mathematics Lesson Differentiate According to Gender, Class and Fields?]', Journal of the Cukurova University Institute of Social Sciences, Vol. 16, No. 1, pp. 33-44.

Bauer, I. M. and Baumeister, R. F. (2011) 'Self-regulatory strength', in Vohs, K. D. and Baumeister, R. F. (ed.), Handbook of selfregulation: research, theory, and applications, pp. 64-82, New York: Guilford Press.

Baumeister, R. F., Heatherton, T. F. and Tice, D. M. (1994) Losing Control: How and Why People Fail at Self-Regulation, San Diego, California: Academic Press.

Betül Cebesoy, Ü. (2013) 'Pre-service Science Teachers' Perceptions of Self-Regulated Learning in Physics', Turkish Journal of Education, January, Vol. 2, No.1, pp. 4-18. https://doi. org/10.19128/turje.181050

Boekaerts, M. (1997) 'Self-regulated learning: A new concept embraced by researchers, policy makers, educator, teacher, and students', Learning and Instruction, Vol. 7, No. 2, pp. 161-186. https://doi.org/10.1016/S0959-4752(96)00015-1

Boekaerts, M. and Niemivirta, M. (2005) Self-Regulated Learning: Finding a Balance Between Learning Goals and Ego-Protective Goals, in Boekarters, M., Pintrich, P. R. and Zeidner, M. (ed.) Handbook of Self Regulation, San Diego: Academic Press. https://doi.org/10.1016/B978-012109890-2/50042-1

Borkowski, J. G. (1992) 'Metacognitive Theory: A Framework for Teaching Literacy, Writing and Math Skills', Journal of Learning Disabilities, Vol. 25, No. 4, pp. 253-257. https://doi. org $/ 10.1177 / 002221949202500406$

Bouffard, T., Boisvert, J., Vezeau, C., and Larouche, C. (1995) 'The Impact Of Goal-Orientation On Self-Regulation And Performance Among College Students', British Journal of Educational Psychology, Vol. 65, No. 3, pp. 317-329. https://doi. org/10.1111/j.2044-8279.1995.tb01152.x

Büyüköztürk, Ş., Çakmak, E. K., Akgün, Ö. E., Karadeniz, Ş. and Demirel, F. (2010) Bilimsel araştırma yöntemleri [Scientific research methods], Ankara: Pegem Yayıncilik.

Can Aran, Ö. (2015) 'Özdüzenleme ve Çalışma Becerileri Arasındaki İlişki', Pegem Eğitim ve Öğretim Dergisi, Vol. 5, No. 2, pp. 207220. https://doi.org/10.14527/pegegog.2015.011

Cavilla, D. (2019) 'Maximizing the Potential of Gifted Learners Through a Developmental Framework of Affective Curriculum', Gifted Education International, Vol. 35, No. 2, pp. 136-151. https://doi.org/10.1177/0261429418824875

Chan, C. K. and Rao, N. (2010) Revisiting the Chinese learner: Changing contexts, changing education CERC studies in comparative education (Vol. 25), Dordrecht: Springer.

Chiang, C. L. and Lee, H. (2016) 'The Effect of Project-Based Learning on Learning Motivation and Problem-Solving Ability of Vocational High School Students', International Journal of Information and Education Technology, Vol. 6, No. 9, pp. 709712. https://doi.org/10.7763/IJIET.2016.V6.779
Cohen, J. (1988) Statistical power analysis fort he behavioral sciences, 2nd edition, Hillsdale, NJ: Erlbaum

Çalışkan, S. and Sezgin Selçuk, G. (2010) 'Self-Regulated Strategies Used by Undergraduate Students in Physics Problems: Effects of Gender and University', Dokuz Eylül University The Journal of Buca Faculty of Education, Vol. 27, pp. 50-62.

Ciolacu, M., Tehrani, A. F., Beer, R. and Popp, H. (2017) 'Education 4.0-Fostering Student Performance with Machine Learning Methods', IEEE 23nd International Symposium SIITME. https://doi.org/10.1109/SIITME.2017.8259941

Creswell, J. W. and Clark, V. L. P. (2016) Designing And Conducting Mixed Methods Research, New York: Sage.

Çekim, Z. and Aydın, S. (2018) Investigation of the Relations between Middle School Student's Motivation to Learn Science and Use of Learning Strategies', Kırlkkale University Journal of Social Sciences, Vol. 8, No. 2, pp. 451-468.

Çokçalışkan, H. (2019) The effect of self-regulation based science teaching on primary school fourth-grade students' selfregulated learning skills, scientific processing skills and achievement, [PhD Thesis], Marmara University, İstanbul.

Dembo, M. H. and Eaton, M. J. (2000) 'Self-regulation of academic learning in middle-level schools', The Elementary School Journal, Vol. 100, No. 5, pp. 473-490. https://doi. org/10.1086/499651

Fraenkel, J. R. and Wallen, N. E. (2006) How to design and evaluate research in education, New York: McGraw-Hill.

Girgin, D. (2020) 'Evaluation of project-based learning process of gifted children via reflective journals', International Journal of Curriculum and Instruction, Vol. 12, No. 2, pp. 772-796.

Grant, A. M., Franklin, J. and Langford, P. (2002) 'The selfreflection and insight scale: A new measure of private selfconsciousness', Social Behavior And Personality, Vol. 30, No. 8, 821-836. https://doi.org/10.2224/sbp.2002.30.8.821

Gröpel, P., Baumeister, R. F. and Beckmann, J. (2014) ‘Action versus state orientation and self-control performance after depletion', Personality and Social Psychology Bulletin, Vol. 40, No. 4, pp. 476-487. https://doi.org/10.1177/0146167213516636

Hargittai, E. and Shafer, S. (2006) 'Differences in Actual and Perceived Online Skills: The Role of Gender', Social Science Quarterly, Vol. 8, No. 2, pp. 432-448. https://doi.org/10.1111/ j.1540-6237.2006.00389.x

Heilbronner, N. N. (2009) Pathways in STEM: Factors Affecting the retention and attrition of talented men and women from the STEM pipeline, [ $\mathrm{PhD}$ Thesis], University of Connecticut, USA.

Hilbert, M. (2014) 'How Much of the Global Information and Communication Explosion is Driven by More, and How Much by Better Technology?', Journal of the Association for Information Science and Technology, Vol. 65, No. 4, pp. 856861. https://doi.org/10.1002/asi.23031

Hockett, J. A. (2009) 'Curriculum For Highly Able Learners That Conforms To General Education And Education Quality İndicators', Journal for the Education of the Gifted, Vol. 32, No. 3, 394-440. https://doi.org/10.4219/jeg-2009-857

Ilgaz, G. (2011) Investigation of elementary learners' perceptions on self-regulated learning strategies, self-efficacy and learner autonomy in science and technology course, [PhD Thesis], Gazi University, Ankara. 
Kirişçi, N. (2013) Self-regulated learning and motivational beliefs of gifted and normal intelligence level students on mathematics, [Ms Thesis], İstanbul University, İstanbul.

Kopp, C.B. (1982) 'Antecedents of Self-Regulation: A Developmental Perspective', Developmental psychology, Vol. 18, No. 2, pp. 199-214. https://doi.org/10.1037/00121649.18.2.199

Kutlu Abu, N. (2018) An evaluation of differentiated science activities for inclusion of gifted students, [PhD Thesis], Amasya University, Amasya.

Lee, I.S. (2002) 'Gender Differences in Self-Regulated On-Line Learning Strategies within Korea's University Context', Educational Technology Research and Development, Vol. 50, No. 1, pp. 101-109. https://doi.org/10.1007/BF02504967

Li, M., Zheng, C., Liang, J. C., Zhang, Y. and Tsai, C. C. (2018) 'Conceptions, self-regulation, and strategies of learning science among Chinese high school students', International Journal of Science and Mathematics Education, Vol. 16, No. 1, pp. 69-87. https://doi.org/10.1007/s10763-016-9766-2

Lipovská H. and Fischer J. (2016) 'Gifted Students and Human Capital Accumulation', Journal on Efficiency and Responsibility in Education and Science, Vol. 9, No. 3, pp. 60-69, https://doi.org/10.7160/eriesj.2016.090302

Lynch, D. J. (2010) 'Motivational Beliefs and Learning Strategies as Predictors of Academic Performance in College Physics', College Student Journal, Vol. 44, No. 4, pp. 920-928.

Maloney, D. M., Ryan, A. and Ryan, D. (2021) 'Developing Selfregulation skills in second level students engaged in threshold learning: results of a pilot study in Ireland', Contemporary School Psychology, Vol. 25, pp. 109-123. https://doi. org/10.1007/s40688-019-00254-z

McClelland, M., Geldhof, J., Morrison, F., Gestsdóttir, S., Cameron, C., Bowers, E., Duckworth, A., Little, T. and Grammer, J. (2018) 'Self-Regulation', in Halfon, N., Forrest, C. B., Lerner, R. M. and Faustman, E. M. (ed.) Handbook of Life Course Health Development, Springer International Publishing: Cham, Germany, pp. 275-298. https://doi.org/10.1007/978-3319-47143-3 12

Ministry of National Education [MoNE], (2018) Fen bilimleri dersi öğretim programı (İlkokul ve ortaokul 3, 4, 5, 6, 7 ve 8. Siniflar) [Science lesson curriculum (Primary and secondary school 3, 4, 5, 6, 7 and 8th Grades)]. Ankara: Millî Eğitim Bakanlığı Temel Eğitim Genel Müdürlüğü.

Moeder-Chandler, M. (2020) Teacher reflective practice and perceptions on overall job satisfaction [PhD Thesis], Trident University International.

Montalvo, F. T. and Torres, M. C. G. (2004) 'Self Regulated Learning, Current and Future Directions', Electronic Journal of Research in Educational Psychology, Vol. 2, No. 1, pp. $1-34$.

Muis, K. R., Chevrier, M. and Singh, C. A. (2018) 'The Role of Epistemic Emotions in Personal Epistemology and SelfRegulated Learning', Educational Psychologist, Vol. 53, pp. 165-184. https://doi.org/10.1080/00461520.2017.1421465

Noushad, P.P. (2008) Cognitions about cognitions: The theory of metacognition, [Online Submission], Available: http://files. eric.ed.gov/fulltext/ED502151.pdf [30 Sept 2020].

Obergriesser, S., Steinbach, J. and Stoeger, H. (2013) 'Emotional experience during participation in a program of self-regulated learning', Symposium at the 3rd International Conference on Talent Development and Excellence (ICTDE), Antalya, Turkey.
Oppong, E., Shore, B. M. and Muis, K. R. (2019) 'Clarifying the Connections Among Giftedness, Metacognition, Self-Regulation, and Self-Regulated Learning: Implications for Theory and Practice', Gifted Child Quarterly, Vol. 63, No. 2, pp. 102-119. https://doi.org/10.1177/0016986218814008

Pallant, J. (2016) SPSS kullanma kılavuzu SPSS ile adım adım veri analizi [SPSS survival manual a step by step guide to data analysis using SPSS], Ankara: Anı Publishing.

Parlak Yilmaz, N. (2005) 'School Goal Structure - Teacher Scale Adapting Into Turkish', Educational Sciences and Practice, Vol.4, No. 7, pp. 129-144.

Patrick, P. G. (2017) Informal Science Educators and the Nine Dimensions of Reflective Practice, in Patrick, P. G. (ed.) Preparing Informal Science Educators (pp. 41-65), Cham: Springer.

Philips, K. (2019) Teaching the Student, Salem Press Encyclopedia.

Pintrich, P. R., Smith, D. A. F., García, T. and McKeachie, W. J. (1991) A manual for the use of the Motivated Strategies for Learning Questionnaire (MSLQ), Ann Arbor: University of Michigan, National Center for Research to Improve Postsecondary Teaching and Learning.

Posner, M. I. and Rothbart, M. K. (1998) 'Attention, Self-regulation and Consciousness', Philosophical Transactions of the Royal Society of London B: Biological Sciences, Vol. 353, No. 1377, pp. 1915-1927. https://doi.org/10.1098/rstb.1998.0344

Powers, E. A. (2008) 'The use of independent study as a viable differentiation technique for gifted learners in the regular classroom', Gifted Child Today, Vol. 31, No. 3, pp. 57-65.

Puncreobutr, V. (2016) 'Education 4.0: New Challenge of Learning', St. Theresa Journal of Humanities and Social Science, Vol. 2, No. 2, pp. 92-97.

Renzulli, J. (1986) 'The three-ring conception of giftedness: A developmental model for creative productivity', in Sternberg R. J. and Davidson J. E. (ed.), Conceptions of giftedness, pp. 51-92. New York: Cambridge University Press.

Renzulli, J. S. and Reis, S. M. (2000) 'The Schoolwide Enrichment Model', in Heller, K. A., Mönks, F. J., Sternberg R. J. and Subotnik, R. F. (ed.), International handbook of giftedness and talent, pp 367-382, Oxford, UK: Elsevier Science Ltd.

Rinn, A. N. and Bishop, J. (2015) 'Gifted Adults: A Systematic Review and Analysis of the Literature.' Gifted Child Quarterly, Vol. 59, No. 4, pp. 213-235. http://dx.doi.org/10.1177/0016986215600795

Salovaara, H. (2005) Achievement goals and cognitive learning strategies in dynamic contexts of learning, [PhD Thesis], University of Oulu.

Schumacker, R. E. and Lomax R. G. (2004) A beginner's guide to structural equation modeling, New Jersey: Taylor \& Francis; pp.1-8.

Schunk, D. H. (2009) Öğrenme teorileri, eğitimsel bir bakışla [Learning theories an educational perspective], Ankara: Nobel Yayın Dağıtım.

Schunk, D. H. and Zimmerman, B. J. (ed.) (1998) Self-regulated learning: From teaching to self-reflective practice, New York: Guilford Press.

Siegle, D. (2013) The underachieving gifted child: Recognizing, understanding, \& reversing underachievement, Waco, TX: Prufrock Press.

Stoeger, H. and Ziegler, A. (2010) 'Do Pupils with Differing Cognitive Abilities Benefit Similarly from a Self-regulated Learning Training Program?', Gifted Educational International, Vol. 26, No. 1, pp. 110-123. https://doi.org/10.1177/026142941002600113 
Stoltz, T., Piske, F., de Freitas, M., D’Aroz, M. and Machado, J. (2015) 'Creativity in education: Contributions from Vygotsky and Piaget', Creative Education, Vol. 6, pp. 64-70. http://dx.doi. org/10.4236/ce.2015.61005

Tabachnick, B. G. and Fidell, L. S. (2013) Using multivariate statistics, 6th edition, Boston, MA: Pearson Education.

Tanti, M., Syefrinando, B., Daryanto, M. and Salma, H. (2020) 'Students' self-regulation and motivation in learning science', International Journal of Evaluation and Research in Education, Vol. 9, No. 4, pp. 865-873. https://doi.org/10.11591/ijere. v9i4.20657

Tezel Şahin, F. (2015) 'A Study into Self Regulation Sufficiencies of the Students Attending to the College Physical Education and Sport', International Journal of Sport Culture and Science, Vol. 3, No. 4, pp. 425-438. https://doi.org/10.14486/IJSCS406

Tortop, H. S. and Eker, C. (2014) 'Why Should Self-regulated Learning Skills Take Place in Gifted Education Programs?', Journal of Gifted Education Research, Vol. 2, No. 1, pp. 23-41.

Uzuntiryaki Kondakçı, E. and Çapa Aydın,Y. (2013) 'Predicting Critical Thinking Skills of University Students Through Meta Cognitive Self-Regulation Skills and Chemistry Self-Efficacy', Educational Sciences: Theory Practice, Vol. 13, No. 1, pp. 666670.

Vaidya, S., Ambad, P. and Bhosle, S. (2018) 'Industry 4.0-Glimpse', Procedia Manufacturing, Vol. 20, pp. 233-238. https://doi.org/10.1016/j.promfg.2018.02.034

Vialatte, F. and Cichocki, A. (2008) 'Split-test Bonferroni correction for QEEG statistical maps', Biological Cybernetics, Vol. 98, No. 4, pp. 295-303. https://doi.org/10.1007/s00422-008-0210-8
Winne, P. H. and Hadwin, A. F. (1998) 'Studying As Self-Regulated Learning', in Hacker, D. J., Dunlosky J. and Graesser, A. C. (ed.) Metacognition in educational theory and practice, $\mathrm{pp}$. 279-306, Hillsdale, NJ: Erlbaum.

Wolters, C. A., Pintrich, P. R. and Karabenick, S. A. (2003) Assessing Academic Self-Regulated Learning. Conference on Indicators of Positive Development: Definitions, Measures, and Prospective Validity.

Yükseltürk, E. and Bulut, S. (2009) 'Gender Differences in SelfRegulated Online Learning Environment', Educational Technology \& Society, Vol. 12, No. 3, pp. 12-22.

Zat, Z. (2018) Investigation the effectiveness of EMDR focused intervention program for increasing self regulated learning on self regulation and trauma symptoms of university students with traumatic experiences related to academic life, [Ms Thesis], Eskişehir Osmangazi University, Eskişehir.

Zimmerman, B.J. (1989) 'A Social Cognitive View of Self-regulated Academic Learning', Journal of Educational Psychology, Vol. 81, No. 3, pp. 329-339. https://doi.org/10.1037/0022$\underline{0663.81 .3 .329}$

Zimmerman, B.J. and Kitsantas, A. (2014) 'Comparing Students' Selfdiscipline and Self-regulation Measures and Their Prediction of Academic Achievement', Contemporary Educational Psychology, Vol. 39, pp. 145-155. https://doi. org/10.1016/j.cedpsych.2014.03.004

Zumbrunn, S., Tadlock, J. and Roberts, E. D. (2011) Encouraging self-regulated learning in the classroom: review of literature, Metropolitan Educational Research Consortium (MERC). 